\title{
移植腎における拒絶反応の診断についての実験的研究
}

\author{
特に組織化学的見地よりの検討 \\ 東京大学医学部泌尿器科教室 村 橋勲
(主售
}

\section{EXPERIMENT ON THE DIAGNOSIS OF THE REJECTION \\ IN THE TRANSPLANTED KIDNEY}

(Histochemical and Biochemical Studies)

Isao Murahashi

Department of urology, Faculty of Medicine, The University of Tokyo, Tokyo

(Director: Prof. H. Takayasu)

Thirty healthy mongrel dogs were used for this study. After bilateral nephrectomy, renal transplantations were done by anastomosing the renal vessels to the common iliac vessels and ureterocutaneostomy was performed simultaneously.

Materials for the histological and histochemical studies were obtained by the open wedge biopsies $4,7,10,12$ and 14 days after transplantation, while control specimens were taken before the operations. The methods of histological and histochemical approach were as follows; hematoxylin-eosin stain, periodic acid-Schiff reaction, fatty stain and reactions for leucine aminopeptidase, alkaline and acid phosphatases, succinic dehydrogenase, lactic dehydrogenase, glucose-6-phosphate dehydrogenase. The level of leucine aminopeptidase (LAP) and alkaline phosphatase (AP) activities were determined in daily urine and serum, and kidney biopsy specimens were also used for the determination of the tissue content of these enzymes.

Histological and histochemical findings of the untreated autograft group were not remarkable. However, atrophy of the tubules with dilated lumen and the deterioration of the enzymatic activity in the tubules were noted in some areas of the treated autograft from 7 to 14 days after transplantations. These changes might indicate one effect of azathioprine. In the untreated homograft group, histological findings were characterized not only by lymphocytic infiltration in the peritubular, perivascular and periglomerular region, but also by the reduction of the enzyma tic activities. Moreover, both LAP and AP in some of the nephrons were strongly affected from the early stage. In the treated homograft group, no marked infiltrations of the lymphocyte were observed. Nevertheless, LAP and AP demonstrated a marked reduction or complete absence, which was followed by the rejection crisis.

Biochemical estimation in the kidney tissue also showed low values of LAP and AP during the rejection reaction. The mirror image was noted on the level of LAP activity in urine and kidney specimen, while such a relationship was absent on the level of AP activity.

Therefore, it may be suggested that the reduction of LAP activity during the rejection crisis is due to the shift of LAP to urine by an alteration of tubular permeability as a result of the immunological attack.

はじめに

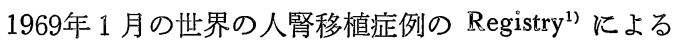
之，その数は 2,347 例に扣よび，本邦における1970年 10 月の四方 ${ }^{2}$ の統計では，168例と報告されている. また その手術成績も年々向上し， 1 年以上のいわゆる長期生 存例は屍体 donor 腎移植例でも約 $42 \%$ となり ${ }^{1)}$ ，従来絶
望的と考えられてきた慢性腎不全患者への大きな光明を 与えるようになつてきている.

しかし、この結果はまだまだ満足すべきものではな い.また。拒絶反応をできる限り早期に発見し，それに 適応した免疫抑制法を施行すること。および慢性拒絶反 応になり，現在の免疫抑制剂ではとらていそれを生着さ 
せることが不可能と思われる場合においては, 過剩の免 疫抑制剤を投与せず移植腎を摘除し，第 2 の腎移植また は人工透析を行なうようにすることも重要なことであ る，つまりこれまでに反省しなければならない点があ り, 第 1 の問題として, 術後 2 カ月以内の早期拒絶反応 時でも，その発見が遅れ，かなり進行した状態の時期に 大量の免疫抑制剤を投与したと考觉られる場合があげら れる. 第 2 の問題点としてほ, 術後第 3 カ月以後の晚期 拒絶反応期になつて, retrospective に久て現在使用され ている, Azathioprine, Prednisolone, Actinomycin, Antilymphocyte serum, Antilymphocyte globulin, 放射線照射 というような免疫抑制療法を強化したことにより惹起さ れたと考兄られる副作用が死因となつていることが多い ことである。

このことは免疫抑制剂の過㮃投与に起因すると考兄ら 机る感染症が，腎移植患者の死因の第 1 位（欧米38.5 $\%$ ，本邦 $28 \%)^{244)}$ をめていること，消化管出血，肝 障害も死因としてかなりみられることからもらなずける ことであろう。拒絶反応の診断および治療に関しては, 臨床所見, 尿, 血液所見, 諸種腎機能検査などにより 総合的に行なわなければならないことはいらまですない が，著者は実際に人腎移植症例の管理にあたり，拒絶反 応時の臨床像は，腎血管系の塞栓症あるいは，尿管の閉 塞などと類似し確診をらることが困難だつた例に遭遇し ている，そこで著者はその早期確定診断の特殊検査法の 一つとして, 数年来, 動物実験で, 腎生検組織につい て, 組織学的面より, とくに酵素組織化学的立場より検 討し, 拒絶反応の早期診断上有用と考光られる所見を得 たのでここに報告する。

\section{実験対象および方法}

雑種成犬 $(12 \sim 26 \mathrm{~kg}) 30$ 頭を, 次のごとく 4 群に分 け。 Nembutal (Pentobarbital) $25 \mathrm{mg} / \mathrm{kg}$ 静注による全身 麻酔下に実験を行なつた。

第 1 群. 自家移植, 免疫抑制剂非投与群 6 頭

第 2 群。自家移植, 免疫抑制剂投与群 5 頭

第 3 群。同種移植，免疫抑制剂非投与群 6 頭

第 4 群。同種移植, 免疫抑制剂投与群 13 頭

第 2 群では免疫抑制剤として, Prednisolone 10mg/日を 筋注, Azathioprine 50mg/日は経口投与した。

第 4 群でも同様な免疫抑制剤投与を行なつたが，実験 犬の全身状態, 尿量, 尿比重, 血液生化学的所見で拒絶 反応と思われる時期には，これらを適宜增量して拒絶反
応の回復とともに再び減量している.

(1) 腎移植手技

血管の縫合は自家移植の場合は，原則として，左腎を 右鼡径部に時に右腎を左絧径部に動脈は外腸骨動脈之喘 々吻合し，静脈は外腸骨静脈と喘側吻合を行ない，同時 に他側腎は摘除した。

同種移植の場合は左右に関係なく, donor 腎を recipient 犬の反対側の単径部に战き, 動静脈吻合は自家移植 と全く同様に吻合した。 その際 recipien $゙$ 犬の両側腎摘 当行なつた.

donor 腎の潅流は摘出後ただちに, Saline $100 \mathrm{ml}$, Dextran $60 \mathrm{~g}$, Heparin 2,000単位, 1\% Procain 1 $\mathrm{ml}$ の混合液を使用し, 静脈側よりの液が清澄となるま で洗滌した。

尿管は尿の採取の正確を計るために単径部に皮膚と縫 合し, splint catheter を留置した。

阻血時間は $24 \sim 40$ 分平均 30 分であつた。

（2）移植犬の術後管理

移植犬ほ術後特製の台上に四肢をしばり，薬剤の投 与, 尿の採取を完全とし, 腎機能検査, 血液および腎生 検を行ない易い上らにし，犬の全身状態とともに，これ らの所見を参考に術後の経過を抢つていつた。

輸液は，5\% Glucose, Lactate Ringer, Saline, 電解 質液を使用し, 経口摂取可能となるまで行ない, 可能と なれば, 牛乳, 固形食物を与え水分は尿量と不感蒸泄に 見合らょうに前記輸液の量は漸減した。そ公の他に感染予 防に抗生物質 (Sodium aminobenzyl penicillin, Cephaloridine, Chloromycetin) を適当飞使用し，免疫抑制剂 投与群には, Azathioprine, Prednisolone を前述のように 使用した。

（3）実験用組織の採取

4 群の実験犬について腎組織の採取は対照として移植 直前に 1 回生検し，移植後は，4，7，10，12，14日目 に開放性に腎生倹を行なつた。

（4）実験材料の検索法

1) 組織学的検索

a. Hematoxylin-Eosin および Periodic acid Schiff Formalin 固定 Paraffin 切片使用した。

b。酵素組織化学的検索

腎生検組織について行なつた酵素染色は, leucine aminopeptidase (以下 LAP と略す), alkaline phosphatase (Alk-P), acid phosphatase (Acid-P), succinic dehydrogenase $(\mathrm{SDH})$, lactic dehydrogenase (LDH), glucose- 
-6phosphate dehydrogenase (G-6-PDH) である。以下に 各酵素の染色法を記す。

1) LAP (Nachlas らの法 ${ }^{5)}$ )

採取組織の処理は開放性腎生娭後直ちに, $10 \times 10 \times 5$ mmの組織塊を作製し。これを acetone, dry ice にて一 $70^{\circ} \mathrm{C}$ 冷却した isopentane 中にて $2 \sim 3$ 分凍結固定し, cryostat に移し, minot rotary microtome で, $8 \mu$ の 組織切片を作製しここれ cover glass と取り，切片は 下記 の染色液に $37^{\circ} \mathrm{C}, 15$ 分間 incubate し，ついで生食 水にて 2 分間洗滌後 $0.1 \mathrm{M}$ 硫酸銅液に 2 分間渗清キニレ 一トし, さらに生食水で 2 分間洗涤し，10\%生食ホルマ リン液にて 5 分間固定し, 生食水で洗滌後, glycerine jellyにて封入した。

\section{染色液 :}

$\begin{array}{llc}\text { 1-leucyl- } \beta \text {-naphthylamide } & \text { hydrochloride } & 8 \mathrm{mg} \\ \text { acetate buffer } & 0.1 \mathrm{M}, \mathrm{pH} 6.5 & 10 \mathrm{ml} \\ \text { sodium chloride } & 0.85 \% & 8 \mathrm{ml} \\ \text { potassium cyanide } & 2 \times 10^{-2} \mathrm{M} & 1 \mathrm{ml} \\ \text { diazo blue B } & & 10 \mathrm{mg}\end{array}$

結果 : 本酵素活性のあるところは青褐色に染色され る。

2) Alk-P (Gomori 法6)

組織切片の作製は前記 LAP の場合と同様にし，作製 後は切片を下記の染色液に $0{ }^{\circ} \mathrm{C}, 15$ 分間 incubate し, 生食水で洗滌後，10\%生食ホルマリン液にて 5 分間固定 し，生食水で再び洗滌し， glycerine jelly で封入した. 染色液 :

$\alpha$-naphthyl phosphate salt

$\begin{array}{llll}\text { borax-NaOH buffer } & 0.1 \mathrm{M}, \mathrm{pH} 9.2 & 20 \mathrm{ml} \\ \text { diazo blue B } & & 20 \mathrm{mg}\end{array}$

結果: 本酵素活性部位が黒褐色飞染色される。

3) Acid-P (Seligman \& Manheimer の法7)

組織切片の作製は前記したと同様に作製後下記の染色 液に $37^{\circ} \mathrm{C} ， 15$ 分間 incubate 乙，生食水で洗涤後，10\% 生食ホルマリン液で 5 分間固定し，生食水で洗涤し， glycerine jelly で封入した.

染色液:

$\alpha$-naphthyl phosphate sali

acetate buffer

$0.1 \mathrm{M}$

diazo blue $B$

10 ing

結果：本酵素活性のあるところは赤褐色に染色され る。

4) SDH (Nachlas \& Seligman の法 ${ }^{8)}$ )
組織切片は $10 \mu$ とその他の処理は前記のものと同様 にして作製した，その後下記の染色液に $37^{\circ} \mathrm{C}, 10$ 分間 incubate し, 生食水で洗滌後10\%生食ホルマリン液にて 5 分間固定し，その後生食水で洗滌し, glycerine jelly にて封入した。

\section{染色液：}

\begin{tabular}{|c|c|c|}
\hline phosphate buffer & $0.2 \mathrm{M} \mathrm{pH} 7.4$ & $10 \mathrm{~m}$ \\
\hline sodium succinate & $0.2 \mathrm{M}$ & $10 \mathrm{~m}$ \\
\hline \multicolumn{2}{|c|}{ nitro blue tetrazolium chloride } & $10 \mathrm{mg}$ \\
\hline phenazine methos & & $1 \mathrm{mg}$ \\
\hline
\end{tabular}

結果：本酵素活性のあるところに青色の diformazan が沈着し, 深青色に染色される。

5) LDH (Nachlas \& Seligman の法9)

組織切片の作製は LAP の時と同様にした. その後下 記の染色液に $37^{\circ} \mathrm{C}, 15$ 分間 incubate し, 生食水で洗湺 後10\%生食ホルマリン液にて 5 分間固定し, その後生食 水で洗滌し, glycerine jellyにて封入した.

染色液:

DL-lactate $2 \mathrm{Na} \quad 1.0 \mathrm{M} \quad 1 \mathrm{ml}$

DPN $10 \mathrm{mg}$

potassium cyanide $2 \times 10^{-2} \mathrm{M} \quad 5 \mathrm{ml}$

$\begin{array}{llllll}\text { phosphate buffer } & 0.06 \mathrm{M} & \mathrm{pH} & 7.4 & 3 \mathrm{ml}\end{array}$

magnesium chloride $\quad 0.005 \mathrm{M} \quad 15 \mathrm{ml}$

nitro blue tetrazolium chloride $20 \mathrm{mg}$

polyvinyl pyrrolidone $15 \mathrm{mg}$

結果：本酵素活性のあるところが青色に染色される.

6) G-6-PDH (Nachlas らの法 ${ }^{10)}$ )

組織切片の作製は LAP などと同様に作製し下記染色 液に $37^{\circ} \mathrm{C}, 15$ 分間 incubate し, 生食水で洗滌後 $10 \%$ 生 食ホルマリン液で 5 分間固定し, 生食水で洗涤後 glycerine jellyで封入した。

染色液：

glucose-6-phosphate $2 \mathrm{Na} \quad 10 \mathrm{mg}$

TPN $5 \mathrm{mg}$

potassium cyanide $2 \times 10^{-2} \mathbf{M} \quad 2 \mathrm{ml}$

magnesium chloride $\quad 0.005 \mathrm{M} \quad 5 \mathrm{ml}$

tris phosphate buffer $\quad 0.2 \mathrm{M}, \mathrm{pH} 7.2 \quad 15 \mathrm{ml}$

sodium fuoride $2 \mathrm{mg}$

phenazine methosulfate $1 \mathrm{mg}$

結果 : 本酵素活性 のあるところが 青紫色に染色され る。

c。 その他の組織検索

1) oil red 0

ホルモール, カルシューム固定後軽く水洗し, 前記し 
た方法にて $8 \mu$ の切片を作製し, 水浸後 $60 \%$ isopropanol 液に30秒浸洗，下記染色液に10分間渗清し，60\% isopropanol 液に 30秒渗清し, その 後水洗, 対染色として, Hematoxylin 染色を行ない, glycerine jelly にて封入 した.

\section{染色液：}

stock solution $6 \mathrm{ml}$

水 $4 \mathrm{ml}$

stock solution $は$ oil red $00.5 \mathrm{~g}, 98 \%$ isopropanol $100 \mathrm{ml}$ を混合したものである.

結果：脂肪は黄赤色に染色される。

2) Nile Blue

切片作製は oil red 0 と同じように行ない，1\% Nile Blue sulfate 溶液に15分間渗清し，急速に水洗後，1\% 酢酸液にて色調一様となるまで弁色，その後水洗し。 glycerine jelly にて封入した.

結果：脂肪は pink または blue 飞染色される。

3) sudan black B

切片の作製は oil red O と同じように行ない，30\%第 3 級ブチルアルュールに 30 秒渗清し，35\%第 3 級ブチル アルュール suden black B 飽和溶液飞 1 時間渗清し, $30 \%$ 第 3 級ブチルアルコールにて 30 秒液清し，水洗後 glycerine jelly にて封入した.

結果：脂肪は黒褐色飞染色される.

2) 生化学的検索

移植腎組織についての LAP, Alk-P 染色の結果は特に 注目すべき変化がえられたので，その変化の mechanism 解明のために，血清，尿，腎組織中の両酵素を生化学的 そ測定した.

測定法は下記のごとくである.

a. LAP (Tuppy らの法 $\left.{ }^{11}\right)$

血清は静脈血を採血後ただちに分離し使用した，尿は 全尿の一部を $0{ }^{\circ} \mathrm{C}, 3,000$ 回転で, 10 分間遠心後の上清 について測定した．組織は腎生検後，0.25M庶糖液を加 学, homogenate 後, $0{ }^{\circ} \mathrm{C}, 3,000$ 回転で30分間遠心後 の上清について測定した.

測定方法は, stock solution 1 (0.05 M phosphate buffer $\mathrm{pH} 7.2) 3 \mathrm{ml}$ と (stock solution 2) $(0.025 \mathrm{M}$ leucine-p-nitranilide) $\quad 0.1 \mathrm{ml}$ 混合液を $25^{\circ} \mathrm{C} ， 5$ 分間 preincubate 乙, その後検体 $0.10 \mathrm{ml}$ を加方, 直ちに波長 $405 \mathrm{~m} \mu$ を使用し, 光電比色計にて測定し, その後 $25^{\circ} \mathrm{C}$ にて30分間 incubate し, 再び波長 $405 \mathrm{~m} \mu$ で比色測定 しこの差すなわち30分間に反応した leucine-p-nitrani- lide の量にて $\mathrm{mu} / \mathrm{ml}$ として測定結果を出した.

b. Alk-P (Bessey-Lowry-Brock 法 ${ }^{12}$ )

検体の処理は LAP の場合と同様にした，測定方法は $0.05 \mathrm{M}$ glycine buffer $\mathrm{pH} 10.5,0.0005 \mathrm{M} \mathrm{Mgcl}_{2}, 0.0055$ M p-nitrophenyl phosphate sodium salt の混合液 $1 \mathrm{mI}$ 飞検体 $0.10 \mathrm{ml}$ を加光, $37^{\circ} \mathrm{C}, 30$ 分間 incubate し, $0.02 \mathrm{~N}$ の $\mathrm{NaOH}$ 溶液にて反応停止後盲検液（前記試薬 を $37^{\circ} \mathrm{C}, 30$ 分間 incubate し, $0.02 \mathrm{~N}$ の $\mathrm{NaOH}$ 溶液を 加えた後に検体 $0.10 \mathrm{ml}$ を加えたもの）を対照として, 波長 $405 \mathrm{~m} \mu$ にて比色測定した.

\section{結 果}

1）犬正常腎に拈ける各酵素の分布は下記の如き所見 であつた。

(1) LAP

犬正常腎の LAP 活性は, 糸球体に極軽度の活性が存 在し，近位尿細管には強度の活性を有し，ヘンレの係 蹄，遠位尿細管には軽度の活性が見られるが，集合管お よび血管壁には活性は存在しない，犬正常腎の LAP 活 性の局在を Schema で第 1 図（その1）に示した.

(2) Alk-P

犬正常腎の Alk-P 活性 は, 近位尿細管に 強度の活性 を有し，血管壁に軽度の活性が見られるが，他の部位に は活性は存在しない. 犬正常腎の Alk-P 活性の局在を Schema で第 1 図（その 2$)$ に示した.

(3) Acid-P

犬正常腎の Acid-P 活性は, 糸球体に軽度, 近位尿細 管に中等度, ヘンレの係蹄には軽度, 遠位尿細管に中等

第 1 図（その 1） 第 1 図（その 2） 第 1 図（その 3） 犬正常腎の L A 犬正常腎のAlk- 犬正常腎のAcid$\mathrm{P}$ 活性の局在 $\mathrm{P}$ 活性の局在 $\mathrm{P}$ 活性の局在
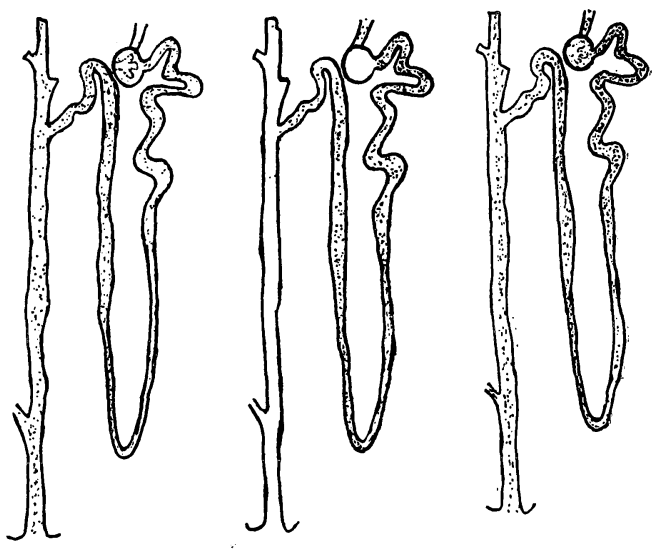
第 1 図（その 4) 第 1 図（その 5) 第 1 図（その 6) 犬正常腎の S D 犬正常腎の L D 犬正常腎の G-6$\mathrm{H}$ 活性の局在 $\quad \mathrm{H}$ 活性の局在 $\quad \mathrm{PDH}$ 活性の局在
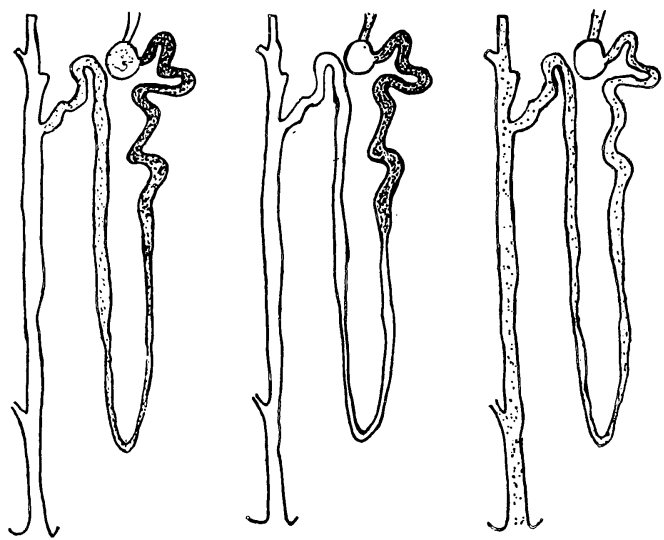

度，集合管および血管壁には極軽度の活性が見られる。 犬正常腎の Acid-P 活性の局在を Schema で第 1 図（そ の 3 ) に示した.

\section{(4) $\mathrm{SDH}$}

犬正常腎の SDH 活性は, 系球体には認められず, 近 位尿細管, ヘンレの係蹄, 遠位尿細管に強度の活性を認 め，集合管，血管壁に極軽度の活性が見られた．犬正常 腎の SDH 活性の局在をSchema で第 1 図 (その4) と 示した。

(5) $\mathbf{L D H}$

犬正常腎の LDH 活性は, 系球体に極軽度, 近位尿細 管に強度, ヘンレの係蹄, 遠位尿細管に軽度, 集合管末 よび血管壁に極軽度の活性を認める。犬正常腎の LDH 活性の局在をSchema で第 1 図（その5）に示した。

(6) G-6-PDH

犬正常腎の G-6-PDH 活性は。糸球体には認めず, 近 位括よび 遠位尿細管，ヘンレの係蹄に軽度の活性を有 し，集合管，血管壁に極軽度の活性が見られる．犬正常 腎の G-6-PDH 活性の局在を Schema で第1 1 図（その 6)に示した。

2）犬移植腎の組織学的所見は以下の如くであつた。

（1）自家移植，免疫抑制剂非投与群について.

H-E, PAS 染色ではほとんど移植による影響は見られ なかつた。

組織化学的には, LAP, Alk-P, Acid-P, SDH, LDH 等 5 種の酵素はいずれも術後 4 日目に極軽度の活性低下が
見られたが，7日目以後は全例術前対照腎と同様の所見 がみられた。一方 G-6-PDH 活性は術後 4 日目に尿細管 に扔いて極軽度の上昇を認めたが，7日目には術前対照 腎と同様の活性が見られた.

脂肪染色では脂肪の存在は全例に認められなかつた。

（2）自家移植，免疫抑制風投与群について。

本群では，H-E, PAS 染色护よび 6 種の酵素染色とも 飞第 1 群と比較し, 大多数例に打いて第 1 群とほぼ同様 の所見であつたが，少数例で術後 7 日目頃に H-E 染色 所見で近位尿細管の一部に細胞萎縮および管腔の拡張等 のみられたものがあり，その部における6 種の各酵素活 性の低下が見られた。

脂肪染色では全例に脂肪の存在を認めなかつた。

（3）同種移植，免疫抑制剤非投与群について。

組織学的所見については，4 日目にすでに peritubular の lymphocytic infiltrationがみられ, 時に perivascular, periglomerular にも cell infiltration がみられた. また 尿細管には腫脹が，糸球体基底膜には肥厚がみられる ものもあつた。 4 日目の H-E 染色所見を写真 1 に示し た.

ついで日を拈つてこれらの cell infiltration はひろが り 7 ～10日目頃には Bowman's capsule の肥厚, 糸球体 係蹄の cell infiltration がみられるようになる. 7 日目 の H-E 染色所見を写真 2 に示した。

ついで, 10〜12日目頃には, 系球体係䁔に hyalinization がみられるようになり，Bowman's capsule 内側には eosinophilic な物質の貯溜するのが見られ，12１4日目 頃には上記所見が出そろつてくる．すなわち皮質全体に lymphocytic infiltration, Bowman's capsule の著明な肥 厚, 間質には, cell infiltration, edema 等がみられるよ らになる。

PAS 染色では,系球体基底膜预よび Bowman's capsule の肥厚部，尿細管の一部に PAS 陽性所見が見られた。

組織化学的所見としては，まず LAP については移植 後，日を和つて活性は低下する，4 日目では尿細管にお ける活性低下は全般的に著明となるが，全く活性の存在 しない尿細管もあり。また正常腎に近い活性を有する尿 細管もあり，その活性分布は一見地図状となる。

術前対照腎の LAP 染色所見を写真 3 に, 4 日目の LAP 染色所見を写真 4 飞示した.

ついで 7 10日目頃になると活性の存在している尿細 管の分布は非常に少なくなりまたその存在している活 性も著明に低下してくる. 
7 日目の LAP 染色所見を写真 5 に示した.

ついで12日目頃には極少数の尿細管に弱い活性をみと めるのみとなり全く活性の見られない例もあつた。

次に Alk-P についてみると, 活性低下の度合が LAP と比較し, やや軽度であるのを除くと, ほぼ LAP の変 化と同様の所見であつた.

次に SDH と LDH については, 活性の低下は比較的 緩徐であつた，10１4日目でも H-E 染色所見で尿細管 に cell infiltration の認められた部位にの及活性の低下 が見られるだけであり，これらの部位にては，LAP， Alk-P .の活性は完全に消失していた.

次に Acid-P については，活性は尿細管に打いては， $\mathrm{SDH}, \mathrm{LDH}$ と核涪同様の変化を示したが，糸球体では 活性の変化のないもの，または軽度上昇の見られるもの もあつた。

次に G-6-PDH については, 活性は移植後 4 日目は正 常または軽度上昇が尿細管においてみられた。ついで日 を扣つて活性は極軽度の上昇傾向を示した．乙かし拒絶 反応の完成したときでもその活性上昇は軽度と思われる 所見であつた。

次に脂肪染色では，7 日目より尿細管に脂肪を認めた ものがあつた。

（4）同種移植，免疫抑制剤投与群について.

組織学的所見としては, 本群の特徴は同種移植免度抑 制剤非投与群と比較し, 間質の lymphocytic infiltration が非常に軽微であり，免疫抑制がうまく行なわれなくな つて，拒絶反応を呈した犬移植腎の H-E 染色所見で も, cell infiltration は第 3 群と比較し軽度であり, ま た cell infiltration は主として peritubular に見られる だけである.

また免疫抑制が適当なときには cell infiltration は見 られないか見られても極軽微である。また間質には時に edema, bleeding が見られるものもある.

組織化学的所見としては，免疫抑制がうまくいつて いる時には，6種の酵素活性はいずれも添正常腎の patternを示す， しかし H-E 染色所見で变化の汪とんぞ 見られない場合でも，4日目または7日目に，LAP お よび Alk-P の尿細管に抢ける活性低下が著明に見られ ることがあり，このような場合にはかならず $2 〜 3$ 日 後に, BUN の上昇, PSP 值の低下, 尿量の減少, 犬移 植腎の腫大など拒絶反応が見られた。これらの変化は Azathioprine, Prednisolone の增量により一部の犬移植腎 では酵素活性は正常犬腎とほ济同様の活性迄数日で回復
第 2 図同種移植，免疫抑制剤投与，一実験例の腎 機能,び血清，尿量及尿，堅組織中 LAP， Alk-P活性の推移。この実験例においては, L A P の尿中活性と腎組織中活性との間に 拒絶反応をかいして mirror image 的関係 が見られる. Alk-P については血清中活性 の上昇があるため尿中活性と腎組織中活性 との間に一連の関係は見い出せなかつた。

Homograft Immunosuppression (t)
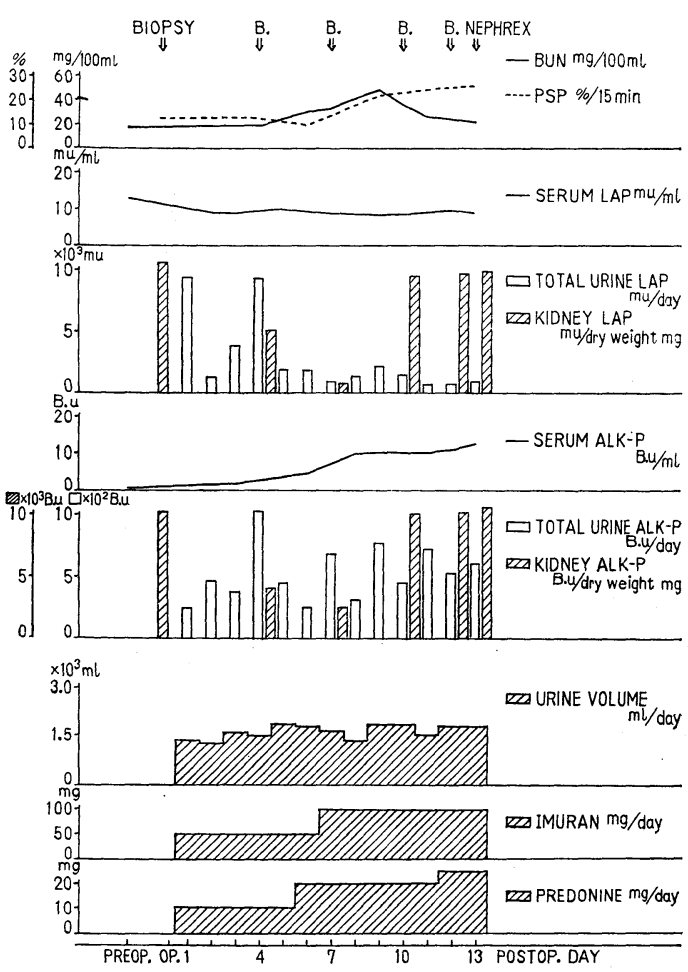

し, BUN, PSP 值も改善し, 尿量も增加してくる. 上 記の如く拒絶反応から回復したと思われる所見を呈した 犬腎移植実験例の腎移植後の血清中, 尿中, 腎組織中の LAP, Alk-P の生化学的測定值 および BUN, PSP 值, 尿量等を第 2 困に示した。 またこの例の術前対照腎の Alk-P 染色所見を写真 6 に, 活性の低下しはじめた 4 日 目のAlk-P 染色所見を写真 7 に，活性の最も低下した 7 日目の Alk-P 染色所見を写真 8 亿, 拒絶反応経過後活性 の回復した13日目の Alk-P 染色所見を写真 9 亿示した.

またこのように LAP, Alk-P の活性の著明な変化の見 られた時でも Acid-P, SDH, LDH, G-6-PDH の活性の変 化は極軽微であつた.

また上記のように拒絶反応より回復した害験群の中 
第 3 図同種移植. 免疫抑制剤投与。一実験例の堅 機能，尿量及び血清，尿，腎組織中 LAP， Alk-P活性の推移。この実験例に抌いては， L A P の尿中活性, 腎組織中活性及び尿量 の減少, 腎機能低下 (拒絶反応) との間に 一連の関係を見い出せるが, Alk-P につい ては, 血清中活性が上年するため, L A P の如き拒絶反応と結びっくような関係は見 い出せなかつた。

Homograft Immunosuppression (t)
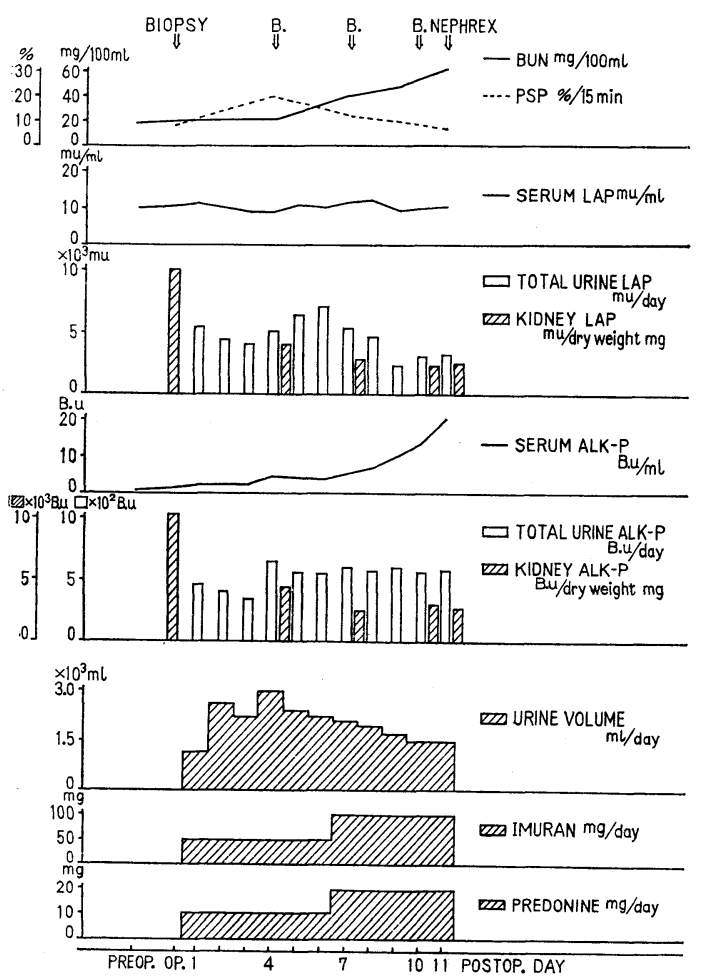

飞, nephron 単位で尿細管の LAP, Alk-P 活性の完全な 消失および Acid-P, SDH, LDH の著明な活性低下を見 たものがあり，当該部位には lymphocytic infiltration も見られた. しかし， G-6-PDH の活性低下は他の 5 種 の酵素と比較し軽度であつた。また特異な所見としてこ のよらな lymphocytic infiltration 抽よび酵素活性の著 明な低下の見られた部位の糸球体には Alk-P の活性が見 られた。

一方免疫抑制が不良となり, 拒絶反応に拈らいつてい く犬移植腎でも組織学的所見は第 3 群と比較し軽微であ るが, LAP, Alk-P の酵素活性は第 3 群とほぼ同様の活 性低下を見た. しかし Acid-P, SDH, LDH, G-6-PDH の
活性変化は著明でなかつた. 同種移植免疫抑制剂投与群 で Azathioprine, Prednisolone の增量にもかかわらず拒 絶反応が回復せず腎機能不全になつた犬腎移植実験例 の血清中, 尿中, 腎組織中の LAP, Alk-P の生化学的測 定値および BUN, PSP 值, 尿量等を第 3 図に示した. またこの例の 4 日目の SDH 染色所見を写真10に， 7 日 目の SDH 染色所見を写真11飞, 11 日目の SDH 染色所 見を写真12に示した.

第 4 群では脂肪染色で脂肪の存在は全例に認めなかつ た.

以上同種移植免疫抑制剂投与群および非投与群の 2 群 のらちで14日以内に拒絶反応を特こさない例は 1 例もな からた.

3）血清中 LAP, Alk-P の変化について.

血清中 LAP については, 自家移植免疫抑制椷投与群 および非投与群との間に差はなかつた。同種移植免疫抑 制剂投与群怙よび非投与群の結果は第 4 図に示したが, 免疫抑制剂投与, 拒絶反応等飞関係なく $5 \sim 21 \mathrm{mu} / \mathrm{ml}$ の值であつた.

\section{第 4 図 同種移植，免疫抑制剤非投与群及び投与群 の血清 LAP 值の推移. 同種移植, 免疫抑 制版非投与及び投与群ともに，術後日数に かかわらず，王よ゙一定の值が見られる。}

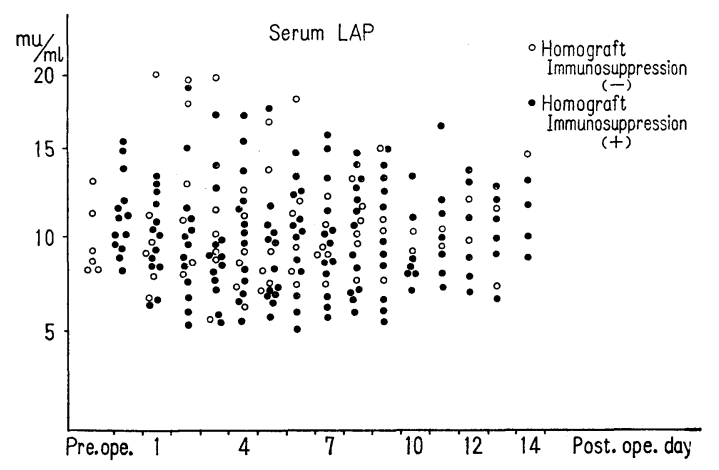

次に Alk-P そついては, 自家移植免疫抑制剂投与群と 非投与群との間には免疫抑制剤の影響と思われる免疫抑 制剤投与群の異常高値が見られた. 同種移植免疫抑制剤 投与群と非投与群との間にも第 5 図に示した如く, 免疫 抑制剂投与群に異常高値が見られた。

4）尿中 LAP, Alk-P の変化について.

LAP については, 自家移植执よび 同種移植, 免疫抑 制風投与拉よび非投与の間に，移植後 $1 \sim 3$ 日間は差は 見られなかつた。 4 日目以後は自家移植群では免疫抑制 
第 5 図 同種多植，兔疫抑制剤非投与及び投与群の 血清A1k-P 値の推移. 同種移植, 免疫抑制 剤非投与群では，術後ほづ一定の值である。 免疫抑制剂投与群では全般的に Alk-P 值 の上昇が見られ，時に異常高值を示すもの もある。

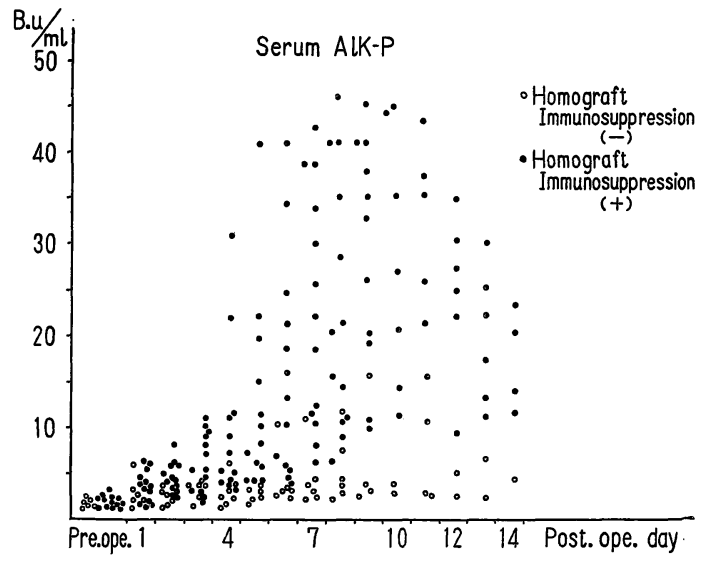

第 6 図 同種移植, 免疫抑制剂非投与群及び投与群 の尿中 LAP 值の推移. 免疫抑制剤非投与 群では術後連日多量に尿中に L A P は排泄 されている.免疫抑制剤投与群では抑制が らまく行われている場合は少量が, 抑制が うまく行われなくなると多量に尿中に排泄 される。

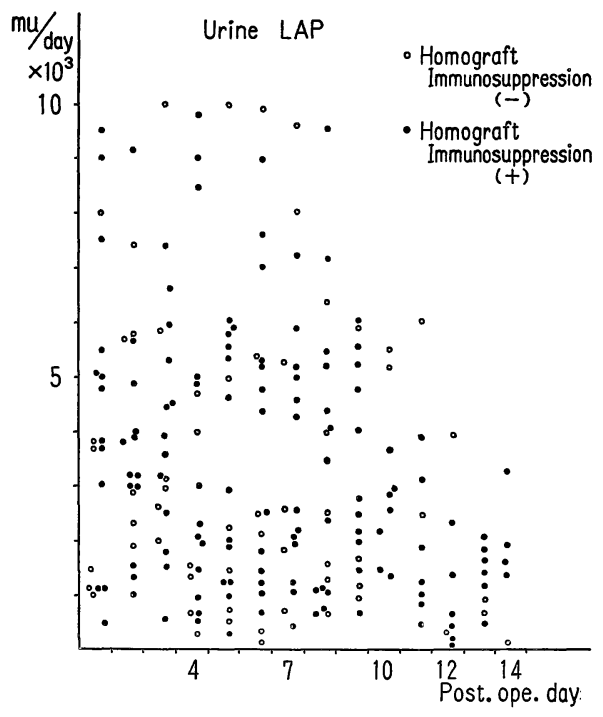

剂投与および非投与群との間に差はなくほぼ一定の値が 連日排泄されている。

一方同種移植，免疫抑制剂投与群および非投与群では
第 7 図 同種移植，免疫抑制剂非投与及び投与群の 尿中Alk-P 值の推移。同種移植，免疫抑制 剤非投与群では術後連日汪よ゙一定量が排泄 されている．免疫抑制剤投与群では血清中 Alk-P 值の上犁が関係してくるため, 拒絶 反応との関係は一概にはいえない。

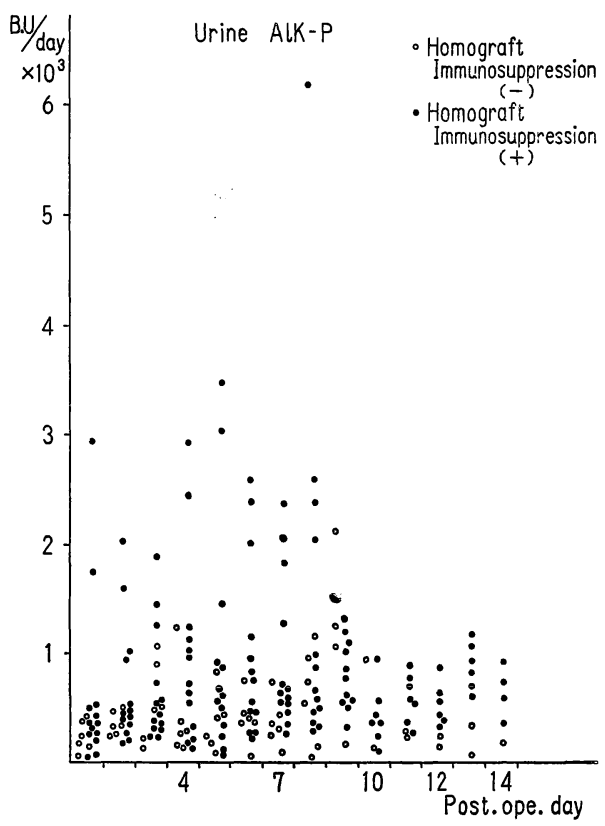

差が見られた. 同種移植 2 群の値について第 6 困に示し たが，免疫抑制剂非投与群では 4 日目以後も連日相当量 が排泄されている.

一方同種移植，免疫抑制剂投与群では，抑制がうまく いつているときは，LAP の尿中排泄は少なく，抑制が 不十分になつてくると尿中に多量に排泄され，その後 2 ～ 3 日後には尿量も減少してくる.

つぎに尿中 Alk-Pについては，自家移植免疫抑制剂非 投与群では LAP と同様の傾向であつたが, 自家移植免 疫抑制剤投与群では血清中 Alk-P の上昇につれて尿中排 泄も増加してくるのが見られた。

一方同種移植免疫抑制剂非投与群および投与群の值を 第 7 図に示したが，免疫抑制剤非投与群では LAP と同 様の傾向を示した. しかし免疫抑制剤投与群では血清中 Alk-P の上昇につれて尿中排泄も増加してくるのが見ら れた.

5）組織中 LAP, Alk-P の変化について.

まず LAP については正常腎では，30例測定し，そ の值は 9,000 16,500 mu/mg.dry.weight 平均 $11,517.5$ mu/mg.dry. weight であつた. 同種移植 2 群の值につい 
第 8 図同種移植，免疫抑制剤非投与及び投与群の 腎組織中LAP值の推移。同種移植, 免疫抑 制剤非投与群では活性は術後漸次低下して いくのが見られる。免疫抑制剤投与群では 抑制が不十分である場合には，活性の著明 な低下を見るが。抑制がらまく行われてい るときには，活性は対照腎とほよ゙同様の值 を示している。

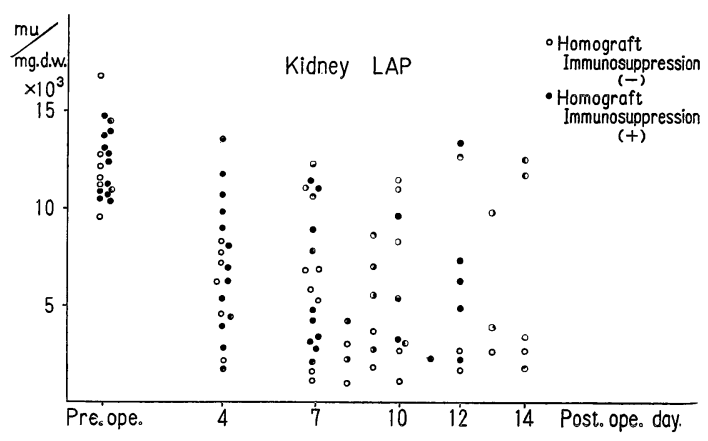

第 9 図 同種移植, 免疫抑制剂非投与群及び投与群 の腎組織中Alk-p值の推移. 同種移植, 免 疫抑制剂非投与群では, 活性は漸次低下し ていく.兔疫抑制剂投与群では抑制が不十 分である場合は，活性の著明な低下を見る が，抑制がらまく行われているときには， 活性は対照腎とほら゙同様の値を示している。

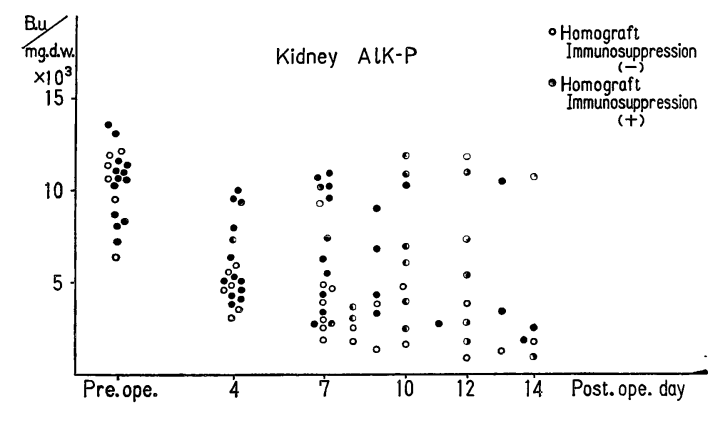

ては第 8 図に示した如く術後 4 日目の値は全例対照腎の 值と比較し。10９0\%の低下をきたしていた。その後は 免疫抑制剤非投与群 では日を扬つて 活性は低下してい く. 一方同種移植免疫抑制剂投与群では，免疫抑制剤の 効果が-十分な場合には活性は対照腎に近い值を示す。し かし免疫抑制がうまく行なわれなくなると活性は低下し てくる.

一方自家移植群では, 術後 4 日目の値は全例対照腎の 值と比較し，10３0\%の低下をきたしていたがその後は 日を経るにしたがい，活性は回復しはじめ。7～10日目
頃にはほ添術前対照腎と同値を示していた。

次に Alk-P そついては，正常犬腎30例を測定し，その 值は 5,800 13,000 B.U/mg.dry. weight 平均 9,329.2 B.U/mg。dry. weiget であつた。同種移植免疫抑制剂非 投与および投与群 2 群の值については第 9 図に示した如 く術後 4 日目の値は全例対照腎の值と比較し $20 \sim 85 \%$ の 低下を示していた，その後の活性の変化は LAP とほぼ 同様であつた。

一方自家移植群では，術後 4 日目の值は，0〜20\%の 低下をきたしていた，その後の活性の変化は LAP と注 ぼ同様であつた。

\section{考 案}

免疫抑制法として十分満足すべきものがなく，かつ組 織適合性についても問題の残されている現状ではやはり 腎に拈ける抗原抗体反応の臨床的表現型としての拒絶反 応を早期に診断することは，腎移植を成功させるための 一つの重要な手段と考兄られる.

この問題を解決する一法として, 拒絶反応時に移植腎 におこつている変化を主として, 酵素組織化学的な面か らとらえようとしたのが著者の試みである。

検討した酵素は第10図に示した様にそれぞれの糖代謝 経路を代表するものとして，G-6-PDH, LDH, SDH をえ らび，蛋白代謝系酵素として，LAP をえらび，その他 腎に拈ける活性が高く, 古くからその存在が知られてい る, Alk-p, Acid-P について検討した.

第10図 解糖系, TCA cycle の脱水素酵素等の作 用点

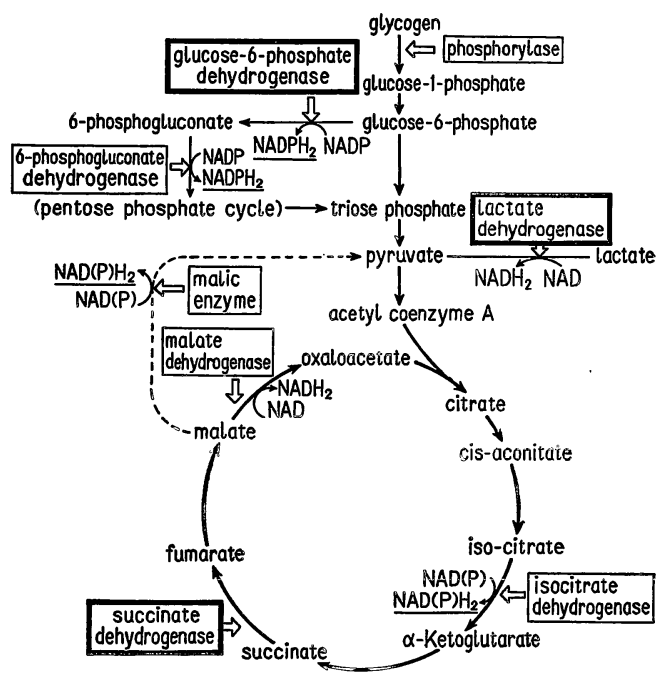


これらの䤉素の染色法および生化学的定量法は広く認 められているところである.

自家移植免疫抑制剤投与群は，阻血およびdenervation の影響に加えるに，免疫抑制剤が間接あるいは直接にど のような影響を腎に与えるかを見るために施行したもの であるが，前記の如く組織学的および酵素組織化学的に は, 自家移植免疫抑制剤投与群と非投与群との間仙大 多数例で差は見られなかつた。

しかし一部の例で見られた軽度尿細管上皮の萎縮およ び尿細管空の拡張は，おそらく，犬の免疫抑制剤に対す る感受性の個体差により肝機能がおかされ，全身状態の 悪化をきたし，腎もその影響を受けたものと思われた。

これらの変化からも免疫抑制剤の投与飞際しては十分 注意しなければならないことが示唆される.

同種移植免疫抑制剤投与群では, いわゆる早期拒絶反 応期のはじまりは，臨床的には勿論であるが，これを形 態学的にとらえることも大変難しい.

これは著者の行なつた動物実験でも示されている.

つまり, 移植後 7 日目になると, H-E 染色標本でる 間質の細胞浸潤, 浮腫, 系球体係蹄基底膜の軽度肥厚な ぞが出現し, 腎移植犬の尿量, 移植腎の腫大, PSP 值 等からも拒絶反応が疑われる状態となるが, 術後 4 日目 の時点では，H-E 染色標本ではほとんど変化は見られ ない。

しかし, 酵素組織化学的染色標本では, すでに変化が みられている。

著者の染色した 6 種の酵素の中では特に, LAP, Alk-P の活性低下が nephron 単位でみられた。

しかし他の 4 種の酵素には注とんど活性の低下が見ら れない.

しかもこの時期に免疫抑制郕を少しずつ増量すると, 拒絶反応をうまくのりきれる場合が多い。

もちろん, 組織適合性が非常に悪い場合には腎機能不 全で死に至ることはいらまでもない。

問題はこの䤉素活性の低下が拒絶反応といら抗原抗体 反応によるものであるかどうかといらことである.

これを直接証明するためには，移植腎に対する抗体に 標識した蛍光抗体をつくり, 监光抗体法を行なつてみる のも一法と考光られ，著者は現在それを試行中であり， 抄つて報告したいと考えている.

しかしこのようなことを行なわなくても，害験動物の 検查結果抢よび経過をよく観察し, 拒絶反応と考兄られ た時期に，免疫抑制剤の投与を增量することによつて，
拒絶反応を抑制すれば，この酵素活性の低下は回復して くること，さらに阻血腎や尿管閉塞による水腎症などの 場合は，少なくともこれらの酵素は一様に低下する傾向 があること ${ }^{13)}$ ，また拒絶反応が進行した状態の時の腎で は, lymphocytic infiltration の出現した部の尿細管で酵 素活性の低下のはげしいことなどからも，今回著者の見 出した変化は，何か抗原抗体反応に起因するものと考兄 られる。

もちろん, 拒絶反応の初期変化は, リンパ管, 小血管 のリンパ球等による閉塞, あるいは血管壁の透過性の增 加による間質の浮腫のための血管系の圧迫によりおこる ものである ${ }^{14)}$ から阻血による原因を全く否定するわけで はない.

また，14日目の酵素染色で，7 日目のものより，LAP， Alk-P をはじめとして, 他の酵素もさらに低下を示し, 活性が殆どみられなくなつているょうな例では，移植腎 の予後は大変悪く, 7 日目の生検材料での酵素活性の 低下度だけでもある程度の移植腎の viability はわかる が，14日目のものと比較するとさらに確実になる.

Lindquist ${ }^{15)}$ らは同種移植免度抑制剂非投与例の 2 日 目の移植腎で, Embden-Meyerhof glycolysis，Krebs' cycle, 脂肪酸酸化系拈よび Hexose-monophosphate shunt に関する脱水素酵素染色を行ない. Hexose-monophosphate shunt の G-6-PDH, 6-PGDH のみ尿細管に和ける活 性增加がみられたが，他の脱水素酵素活性はすべて減少 していたとのべているが，拒絶反応との関係については 言及していない，著者も同種移植免疫抑制剤非投与群で 同様の傾向をみとめ, 免疫抑制剤投与群では術後 4 日目 飞多少活性上昇がみられ，拒絶反応時上昇の傾向にあ る. その原因は抗原抗体反応で enzyme の inhibiter が 消費されること, 本酵素の産生の增加, あるいは尿細管 細胞の透過性の变化で, 血中, 尿中への流出が阻害され ることなどが考えられる.

系球体の変化については，ここには本来酵素活性の余 りない場所であるが，Alk-P に関しては，拒絶反応が進 行し尿細管における活性が低下してくると逆に糸球体に 活性が出現し, その局在は, PAS 染色の濃染する部と ほぼ一致し，糸球体係蹄の肥厚した基底膜に附着してい

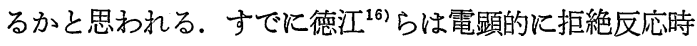
飞 subendothelial に濃度の低い何かが deposit している ことを報告しており，当然ながら早期拒絶反応時にも糸 球体に何らかの変化が抗こり, 本来の糸球体から尿中に 漏出する管の Alk-P がここに附着したことが一つの原 
写真 1 同種移植，兔疫抑制剂非投与 4 日目，H-E 染色. ごく軽度の peritubular, periglomerular の cell infiltration 及び尿細管上皮の菱縮, 管腔の拡張等が見られる。 $(\times 100)$

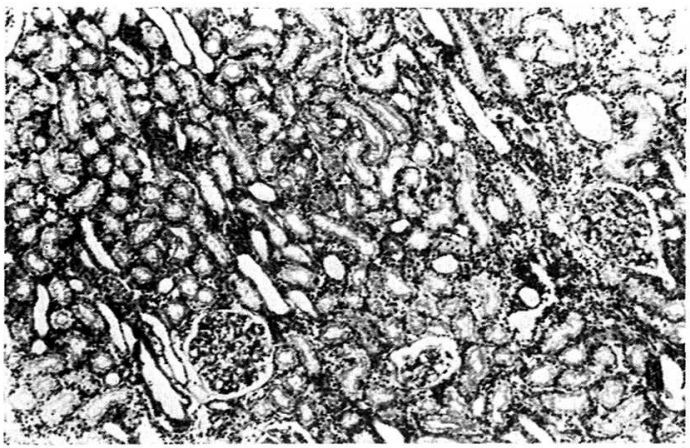

写真 3 犬正常腎の LAP 染色. 系球体に極軽度, 近位尿細管に強度, ヘンレの係蹄, 遠位尿 細管に柽度の活性をみるが，集合管には活 性は見られない. $(\times 100)$

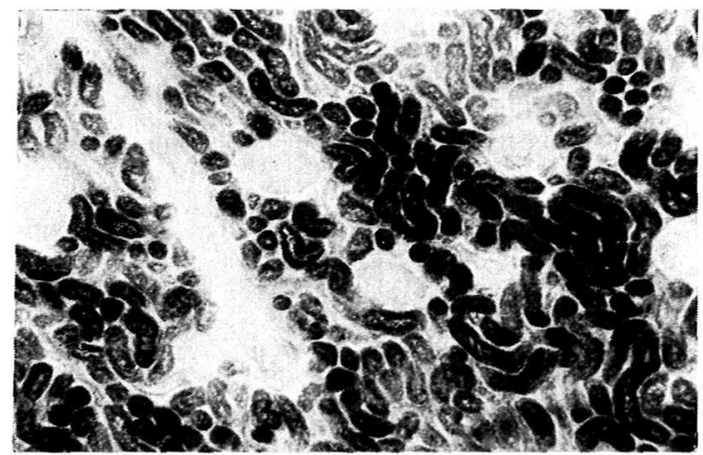

写真 5 同種移植，兔疫抑制剂非投与，7日目. LAP染色.ごく一部の尿細管に怪度の活性 を認めるのみとなつてきている，(×100)

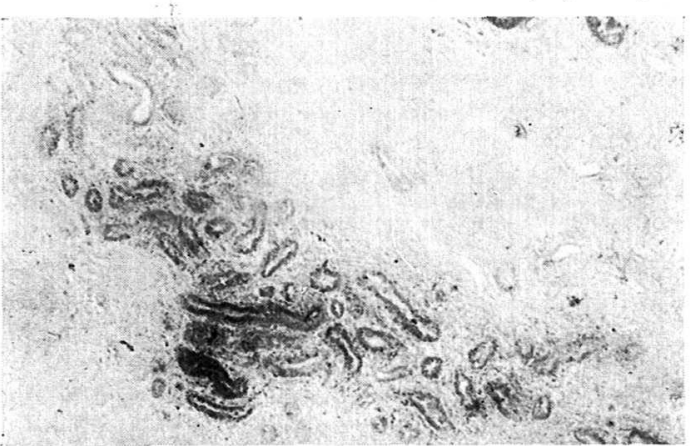

写真 2 同種移植，免疫抑制剂非投与 7 日目, H-E 染色. 皮質全体に lymphocytic infiltration, Bowman's capsule の著明な肥厚，系球体 係蹄の cell infiltration, 尿細管上皮の萎 縮等が見られる。(×100)

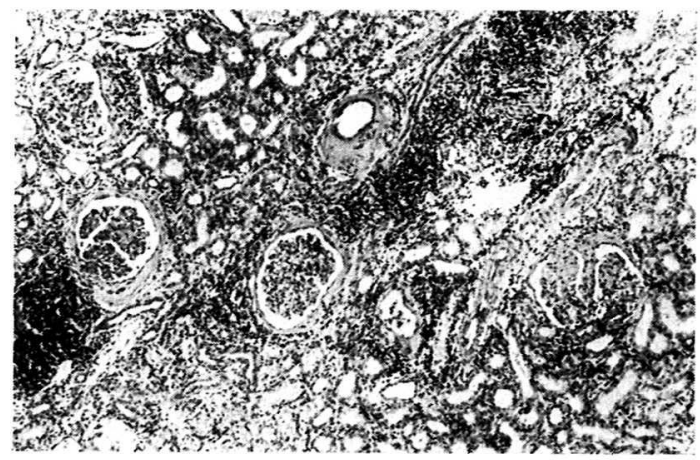

写真 4 同種移植，兔疫抑制剂非投与，4 日目， LAP 染色. 全般的に尿細管の著明な活性 低下が見られるが，一部の尿細管では正常 に近い活性を有し，又一部の尿細管では完 全な活性の消失が見られる。( $(\times 100)$

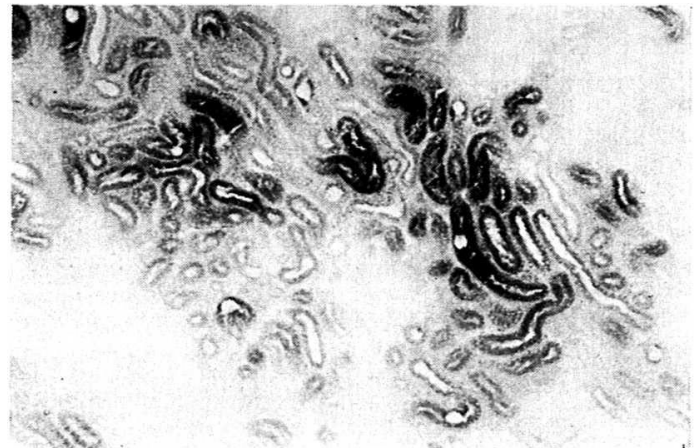

写:真 6 犬正常腎 Alk-P 染色. 近位尿細管に强い 活性が見られるが，糸琭体やその他の部位 には活性は見られない，(×100）

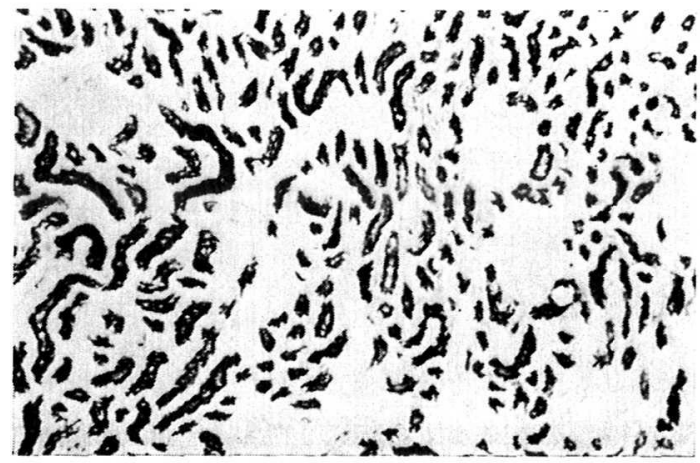


写真 7 同種移植，兔疫抑制剂非投与，4 日目， Alk-P 染色（拒絶反応初期）。一部の尿細 管では，正常の活性が見られるが，一部の 尿細管では極軽度の活性をみる。即ち地図 状の活性低下が見られる。( $\times 100)$

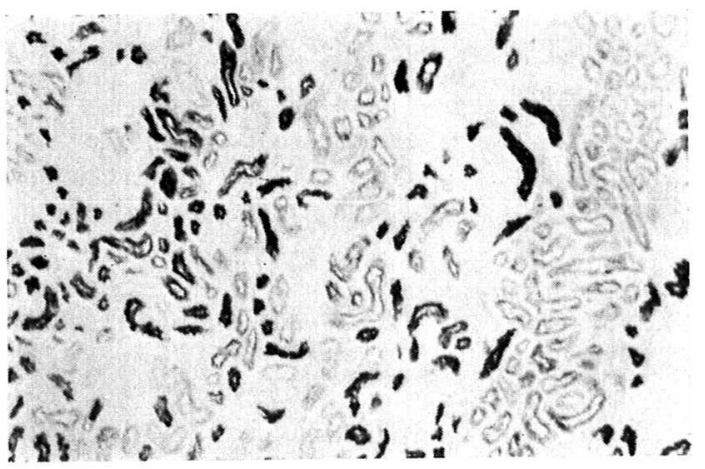

写真 9 同種移植，免疫抑制剂投与,13日目, Alk-P 染色(拒絶反応回復期). 一部の尿細管で完 全な活性の消失を見るが，大部分の尿細管 では，ほら゙正常の活性が見られる，又一部 の系球体で軽度の活性が見られる. $(\times 100)$

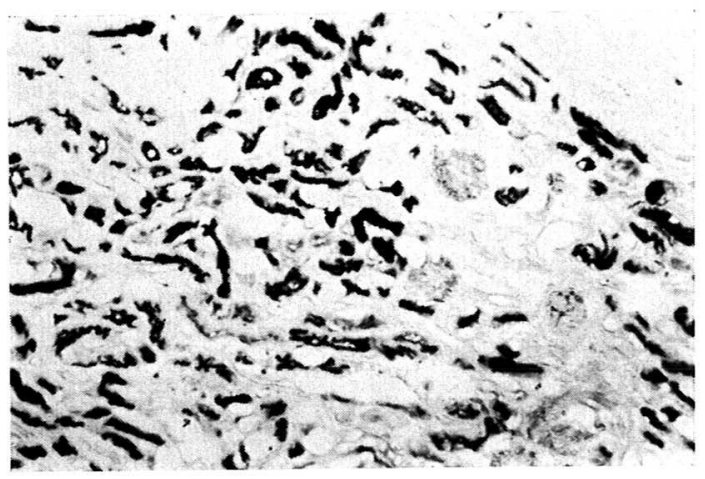

写真11 同種移植，免疫抑制剂投与，4日目, SDH 染色 (拒絶反応初期). 4 日目の活性(写真 10)とほぶ同様の活性が見られる. (×100)

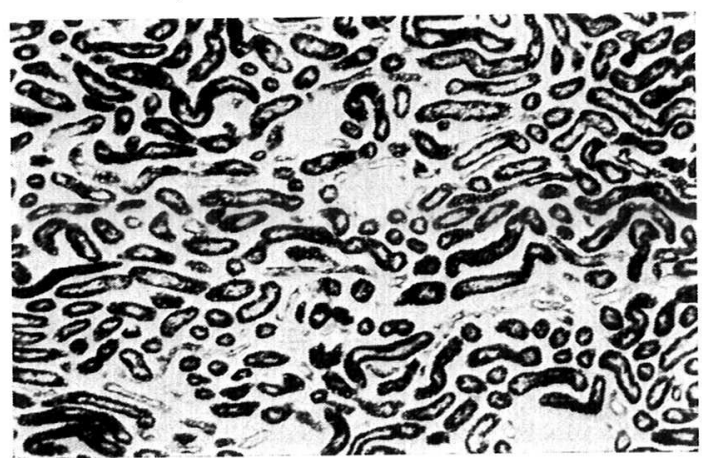

写真 8 同種移植, 免疫抑制剤投与, 7 日目, Alk$\mathbf{P}$ 染色 (拒絶反応極期). ごく一部の尿細管 にほぶ正常に近い活性を認めるが，大部分 の尿細管では活性の著明な低下又は活性 の完全な消失が見られる。（×100）

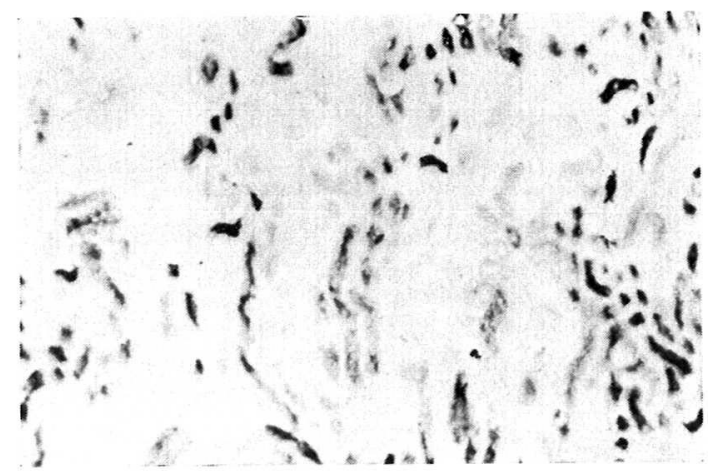

写真10 同種移植,免疫抑制剂投与, 4 日目 SDH染 色(拒絶反応極期). 系球体飞は活性は見ら れないーレンの係踩, 近位, 遠位尿細管に 強い活性が見られる。この活性所見は術前 対照腎とほら゙同様の強さである。（×100）

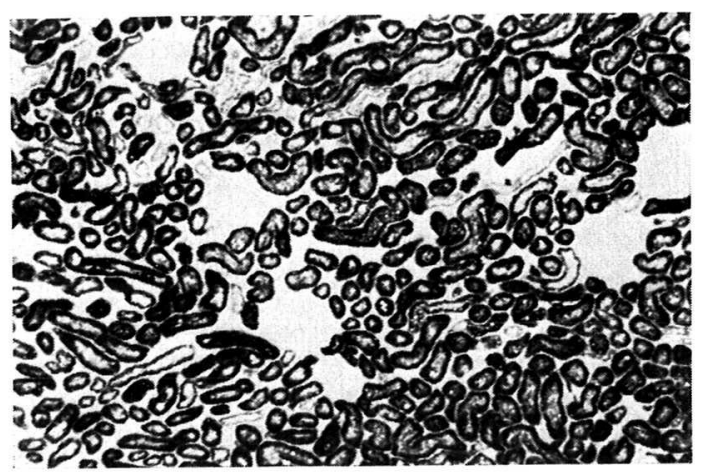

写真12 同種移植，兔疫制剂投与，11日目，SDH染 色 (無尿期).4日目(写真10) 及び 7 日目 (写真11）と比較し，活性にはさほど変化 が見られない。 $(\times 100)$

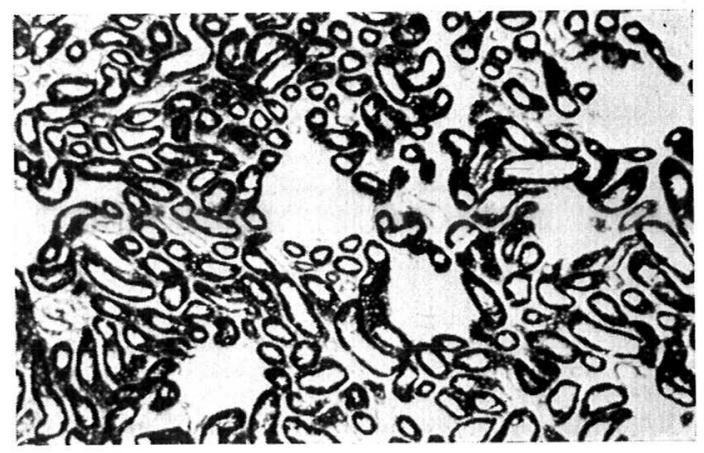


因となり血清中 Alk-P も上昇すると考光られる．Vink ${ }^{17)}$ らも同様の事実を認めているが，その原因は抗原抗体反 応により采球体の permeability が二次的に六進したた 凶系球体係蹄に Alk-P が増加したと述べているが，著者 の見解では, 糸球体基底膜の肥厚等前記した如き系球体 の変化により permeability が低下し, Alk-P が眝溜し たと考えており彼らとは逆のよらである。いずれにせよ 糸球体への Alk-P 活性の出現の程度が予徐判定の一助と なりそうである。

次に LAP, Alk-P の腎組織中活性が低下することの mechanism の検討のために，血清中，尿中および組織中 の活性を生化学的に測定したが，LAP については拒絶 反応時にも血清中の活性には著変は見られなかつたが， 尿中の活性は增加し, 腎組織中の活性の減少がみられ， 後二者は mirror image 的関係にあり, LAP の組織中 の活性低下は尿細管壁の permeability の変化により本 酵素が尿中に逸脱するためと考えら劣たた。

Alk-P については，血清中の活性は免疫抑制剂の肝へ の影響も考兄られ，日を経るにしたがつて上昇してく る. そして尿中活性も增加してくるた命組織活性と尿中 活性に一連の関係を見い出せなかつた．乙かし血清中活 性に関係なく組織中活性と酵素組織化学的所見とはほぼ 行平関係にあつた。

な怙 Azathioprine, Prednisolone 投与時の開放性腎生 検に際しては感染に十分注意しなければならないが，著 者はこの操作により状態の悪化した例は経験していな い.

人腎移植症例でも，オーストラリアの Kincaid-Smith ${ }^{18)}$ らは針生検の有用性を報告しているが，安全で十分確 実に組織を採取できる開放性生検の方が診断的価值は高 く，治療方針決定上有用と言觉そらである。

\section{結 語}

1）腎生検組織で，LAP, Alk- P 染色は拒絶反応時に 他の醳素より早く活性が低下し，その早期診断，予後判 定上有用である. 反対に G-6-PDH 染色では拒絶反応時 に多少上昇の傾向がある.

2）これらの酵素活性の低下あるいは上昇は nephron 単位でみられ, その結果拒絶反応時の標本は地図状の染 色状態是する。

3）早期拒絶反応は尿細管のみでなく，当然ながら采 球体にも扝こつてくる。

4）拒絶反応時の腎組織内 LAP 活性の低下は抗原抗 体反応により尿細管の permeability が変化したため, 腎組織中の LAP が尿中に漏出したためと考えられる. 本論文の要旨は, 第 7 回, 第 8 回, 第 9 回日本組織細
胞化学会総会（1966年11月，1967年11月，1968年11月） 及び第56回日本泌尿器科学会総会 (1968年 4 月) におい て発表した。

稿を終るに臨み高安久雄教授の御指導及び御校閲に深 甚な謝意を表すると共に直接御指導下さつた阿曾佳郎講 師, 星野嘉伸博士。小磯謙吉博士並びに移植突験に御協 力戴いた北川竜一講師はじめ医局諸先生方に感謝いたし ます。本研究の一部は文部省科学研究費によるものであ る。

\section{文献}

1) Advisory Comittee of the Human Kidney Transplant Registry: Transplantation, 8: 721 1969 .

2) 四方統男: 第13回日本腎臟学会総会, シンポジ アム, 腎移植にてロ演, 1970.

3) Simmons, R.L., Tallent, M.B., Kjellstrad, C.M. and Najarian, J.S.: Am. J. Surg., 119: 553, 1970.

4) Murray, J.E., Gleason, R.E., and Atkinson, J.C.: Transplantation, 5: 752, 1967.

5) Nachlas, M.M., Crawford, D.T. and Seligman, A.M.: J. Histochem. Cytochem., 5:264, 1957

6) Gomori, G.: J. Lab. Clin. Med., 37: 526, 1952.

7) Seligman, A.M. and Manheimer, L.H.: J. Natl. Cancer. Inst., 9: 427, 1949.

8) Nachlas, M.M., Isou, K.C., Souzo, E.D., Cheng, C.C. and Seligman, A.M.: J. Histochem. Cytochem., 5: 420, 1957.

9) Nachlas, M.M., Walker, D.G. and Seligman, A.M.: J. Biophys. Biochem. Cytol., 4: 29, 1958.

10) Nachlas, M.M., Walker, D.G. and Seligman, A.M.: J. Biophys. Biochem. Cytol., 4: 467, 1958.

11) Tuppy, H., Wiesbauer, U. und Wintersberger, E.: Hoppe-Seylers. Zschr. physiol. Chem., 329: 278, 1962.

12) Bessy, O.A., Lowry, O.H. and Brock, M.J.: J. Biol. Chem., 164, 321, 1946.

13）阿曾佳郎：日泌尿会誌，53，243,1963。

14) Kountz, S.L., Williams, M.A., Williams, P.L., Kapros, C. and Dempster, W.J.: Nature, 199, 257, 1963.

15) Lindquist, R.R. and Hager, E.B.: Ann. N.Y. Acad. Sci., 120, 50, 1964.

16) 德江章彦, 横山正夫, 岡田清己, 高安久雄 : 第 57 回日本泌尿器科学会総会にてロ演, 1969.

17) Vink, B.V.H. and Willighagen, R.G.J.: Transplantation, 5: 420, 1967.

18) Mathew, T.H., Kincaid-Smith, P., Eremin, J. and Marshall, V.C.: Med. J. Aust., 1: 6, 1968.

19）高安久雄, 小磯謙吉: 小児科診潦, $33,453,1970$ 。 (1971年6月18日受付) 